\title{
Review \\ Oestrogen exposure and breast cancer risk
}

\section{Ruth C Travis and Timothy J Key}

Cancer Research UK, Epidemiology Unit, University of Oxford, Oxford, UK

Corresponding author: Ruth Travis (e-mail: ruth.travis@cancer.org.uk)

Published: 28 July 2003

Breast Cancer Res 2003, 5:239-247 (DOI 10.1186/bcr628)

(C) 2003 BioMed Central Ltd (Print ISSN 1465-5411; Online ISSN 1465-542X)

\begin{abstract}
Epidemiological and experimental evidence implicates oestrogens in the aetiology of breast cancer. Most established risk factors for breast cancer in humans probably act through hormone-related pathways, and increased concentrations of circulating oestrogens have been found to be strongly associated with increased risk for breast cancer in postmenopausal women. This article explores the evidence for the hypothesis that oestrogen exposure is a major determinant of risk for breast cancer. We review recent data on oestrogens and breast cancer risk, consider oestrogen-related risk factors and examine possible mechanisms that might account for the effects of oestrogen. Finally, we discuss how these advances might influence strategies for reducing the incidence of breast cancer.
\end{abstract}

Keywords: breast cancer, epidemiology, oestrogen, prevention, risk factors

\section{Introduction}

Epidemiological and experimental evidence implicates oestrogens in the aetiology of breast cancer. Most established risk factors for breast cancer in humans are thought to influence risk through hormone-related pathways [1], increased concentrations of endogenous oestrogens are strongly associated with increased risk for breast cancer in postmenopausal women [2], and trials have shown that the anti-oestrogens tamoxifen and raloxifene reduce the incidence of breast cancer [3]. Furthermore, experimental studies in animals have shown that oestrogens can promote mammary tumours, and a decrease in exposure to oestrogens, by performing an oophorectomy or giving an anti-oestrogenic drug, has the reverse effect [4]. However, the effects of oestrogen alone do not fully account for the relationships observed between breast cancer and hormone-related risk factors. Other hormones, such as progesterone [1], prolactin [5] and testosterone [6], may also be important.

This article explores the evidence for the hypothesis that exposure to oestrogen is a major determinant of risk for breast cancer. It is not intended to be a comprehensive review but rather focuses on recent epidemiological and experimental data relating to the role of oestrogen in the aetiology of breast cancer and possible mechanisms that might account for the association. There are several forms of oestrogen, the principal form in humans being oestradiol, but for convenience in this article we refer generally to oestrogens except where it is necessary to be more specific.

\section{Reproductive risk factors, oestrogen and breast cancer}

Oestrogens have an essential role, together with other hormones, in the development of the female sex organs and secondary sex characteristics, the regulation of the menstrual cycle and reproduction. Thus, it has been proposed that the effects of many established reproductive risk factors for breast cancer are mediated by hormonal mechanisms, for the most part involving oestrogens [1].

Although risk for breast cancer increases with age, there is a marked decline in the rate of increase in risk with age following the loss of ovarian function, either as a result of a bilateral oophorectomy or due to the menopause $[7,8]$, showing that hormone production by the ovaries is a crucial risk factor for breast cancer in humans. The duration of exposure to ovarian hormones seems to be closely related to breast cancer risk: a 1-year delay in the 
onset of menarche is associated with a 5\% reduction in risk for developing breast cancer in later life [9], and each 1 -year delay in the onset of menopause is associated with a $3 \%$ increase in risk [7].

Epidemiological studies have also firmly established associations between risk for breast cancer and other reproductive factors, including nulliparity (having no children) or low parity, late age at first birth, and breast feeding [10]. After a transient increase in risk for breast cancer, peaking at about 5 years after giving birth [11], having at least one child is associated with a decrease in the long-term risk of developing breast cancer compared with risk among the nulliparous, and this protective effect increases with number of children [12]. Each birth reduces the relative risk of breast cancer by an average of $7 \%$ [12]. The reduction in risk per birth is greater for births at young ages than older ages, such that women who have their first birth before the age of 20 years have a 30\% lower risk than women with a first birth after the age of 35 years [13].

A mechanism involving oestrogens, and probably other hormones, has been proposed to explain both the transient increase in risk and the reduced risk in the long term associated with pregnancy. The very high serum levels of oestrogens and progesterone during pregnancy stimulate growth of the mammary epithelium and also promote the differentiation of epithelial tissue, reducing the number of epithelial structures most vulnerable to malignant transformation [14]. Thus, the short-term effect of pregnancy may be to promote the growth of cancer if a malignant transformation is present in the breast, but in the longer term the risk for breast cancer is reduced. In contrast, malignant transformations are more likely to have accumulated in the breast tissue of older women, and there might therefore be a higher risk of cancer developing in these women when breast cells are stimulated to divide during pregnancy. The effect of age at first birth highlights the importance of timing of exposure as a critical determinant of the effects of steroid hormones such as oestrogen.

Breast feeding is associated with a modest decrease in risk for breast cancer, above and beyond that associated with multiple pregnancies (4\% for every 12 months of breast feeding) [12]. This effect might be due to the suppression of ovulation, reducing exposure to ovarian hormones.

\section{Diet-related and lifestyle factors in relation to breast cancer}

Two diet-related factors, high alcohol intake [15] and obesity [16], are established risk factors for breast cancer. A moderate intake of alcohol (one unit a day) increases risk by $7 \%$, and higher intakes of alcohol increase risk in an approximately linear fashion. The mechanism for this effect remains unknown but has been proposed to involve increased concentrations of circulating oestrogens $[15,17]$. Breast cancer risk among postmenopausal women is also strongly associated with body mass index (BMI, an index of body weight independent of height, calculated as body weight in kilograms divided by the square of the height measured in metres). Risk for breast cancer is increased by $30 \%$ among obese postmenopausal women (with a BMl of more than $30 \mathrm{~kg} / \mathrm{m}^{2}$ ) compared with those with a normal BMI (less than $25 \mathrm{~kg} / \mathrm{m}^{2}$ ) [16]. This association is probably due to the relationship between $\mathrm{BMI}$ and endogenous oestrogen concentrations because, in postmenopausal women, circulating oestrogen concentrations are dependent on the extraglandular production of oestrogen in the adipose tissue.

For premenopausal women, the lack of a positive association of BMI with breast cancer risk [16] is consistent with the facts that most oestrogen is produced by the ovaries and that levels are homeostatically regulated by a negative feedback system involving gonadotrophins (follicle-stimulating hormone and luteinising hormone). Thus, oestrogen concentrations in premenopausal women are not directly affected by the levels of adipose tissue. Indeed, obesity in premenopausal women has been linked to a slight decrease in risk for breast cancer [16], possibly mediated through an increase in the occurrence of anovulatory cycles and a subsequent decrease in exposure to ovarian progesterone among these women (see below). It has been suggested that this decrease in breast cancer risk due to obesity in early adulthood may continue into later life, negating some of the increased risk of breast cancer among women who remain obese after the menopause [18]. Evidence for this comes from the finding that weight gain from adolescence to adulthood is most strongly and consistently associated with risk of postmenopausal breast cancer [16], with weight gains of over $20 \mathrm{~kg}$ associated with an increase in risk of $40 \%$ [19].

Physical activity has also been observed to be associated with a reduced risk for breast cancer in both premenopausal and postmenopausal women. Most studies have found a $20-40 \%$ decrease in risk of breast cancer among the most physically active [16]. The effects of physical activity on breast cancer risk may be mediated through alterations in endogenous hormones including oestrogens, energy balance, body mass and possibly immune function [20]. In postmenopausal women this low risk might be due in part to physical activity preventing weight gain and obesity [20], although there is some evidence to suggest that the effects of physical activity are independent of weight control [21]. In premenopausal women the effects of high levels of physical exercise may be mediated by other mechanisms [20]. For example, there is considerable evidence that intense physical activity can alter menstrual cycle characteristics, delay menarche and increase the probability of anovulatory cycles, 
amenorrhoea or oligomenorrhoea, thus reducing exposure to ovarian hormones $[20,22-24]$, and there is also some promising evidence that even moderate exercise may be beneficial [25-27].

\section{Endogenous oestrogens and breast cancer in humans}

Direct evidence for a relationship between oestrogens and risk of developing breast cancer comes from observational studies that have found circulating and excreted oestrogen levels to be associated with risk for the disease [28]. Because breast cancer itself might affect hormone production, it is necessary to conduct prospective studies of oestrogens and breast cancer risk in which samples are collected at the start of the study from healthy women, who are then followed up with respect to cancer diagnoses. Such investigations have considered premenopausal and postmenopausal women separately because the endogenous production of and exposure to endogenous oestrogen varies greatly during a woman's lifespan. In premenopausal women, the predominant form of circulating oestrogen is oestradiol secreted by the ovaries in cyclical monthly patterns. After the menopause, however, the production of oestrogens in the ovaries ceases and the major source of oestradiol is by conversion from oestrone, itself produced mostly through the peripheral conversion of androgen precursors, predominantly androstenedione, in extraglandular tissue such as adipose tissue [29].

A recent pooled analysis of nine prospective studies in postmenopausal women, including 663 breast cancer cases, found a highly significant increase in breast cancer risk with increasing concentrations of oestradiol, free oestradiol and oestrone in the blood [2]. Postmenopausal women with relatively high serum oestrogen concentrations had an approximately twofold risk of breast cancer compared with postmenopausal women with relatively low serum concentrations of sex hormones [2]. Studies have also evaluated the relationship between urinary endogenous oestrogens and breast cancer; recent results from the largest prospective study of oestrogens and breast cancer found women with a higher excretion of oestrone and oestradiol to have a significantly increased risk for breast cancer [30].

Data on oestrogen levels in premenopausal women and breast cancer risk are sparse, with only five small prospective studies published so far [31-35]. Of the three larger and more recent studies, two found a nonsignificant increase in mean oestradiol concentrations among cases in comparison with controls [33,34], and the third reported significantly elevated levels of bioavailable oestradiol and a nonsignificant increase in total oestradiol in cases [35]. These results are compatible with the oestrogen hypothesis, but the numbers studied are too small, and the difficulties of appropriate adjustment for day of menstrual cycle too complex, to allow any firm conclusions.

A limitation with all these studies is that they rely on measurements made from just one sample, and whereas measurements in single samples from postmenopausal women have been found to be fairly representative of long-term circulating oestrogen concentrations, single sample measurements from premenopausal women are less representative of average circulating concentrations $[36,37]$. The reliable estimation of circulating oestrogen concentrations in premenopausal women is complicated by the fluctuating levels of oestrogen over the course of the menstrual cycle, such that the timing of the sample is a strong determinant of the oestrogen concentration measured.

\section{Binding proteins and the bioavailability of oestrogens}

The availability of oestrogen in tissues is determined not only by the production of the hormone and concentrations in circulation but also by the extent to which it is bound to a binding protein, sex-hormone-binding globulin (SHBG). Thus, high concentrations of SHBG decrease the proportion of oestradiol that is able to leave the circulation and enter the cells. SHBG might partly mediate the effects of obesity in postmenopausal women because obesity is associated with lower levels of SHBG [36] and an inverse association has been observed between concentrations of SHBG and breast cancer risk in postmenopausal women [2]. So far, however, the few studies that have investigated the relationship between SHBG and breast cancer risk in premenopausal women have failed to find an association $[34,35,38]$.

\section{Genetic determinants of endogenous hormones in relation to breast cancer risk}

The genetic control of oestrogen levels has recently received much attention and with it the notion that susceptibility to breast cancer might in part be determined through germline polymorphisms in metabolic genes, specifically those encoding enzymes involved in the biosynthesis and metabolism of oestrogens [39]. Further, it has been suggested that small effects of individual polymorphisms in genes involved in steroid biosynthesis and catabolism might be cumulative [40]. Such polymorphisms might be particularly important among postmenopausal women, in whom oestrogen production is not homeostatically controlled by pituitary gonadotrophins. Several recent epidemiological studies have observed an association between risk for breast cancer and polymorphisms in genes involved in oestrogen synthesis, such as CYP17 and CYP19, and in HSD17B1, which codes for an enzyme that converts oestrone to oestradiol $[40,41]$. However, other studies have not found an association between such polymorphisms and breast cancer, and a 
biological relationship of these polymorphisms with circulating oestrogens and oestrogen metabolites has yet to be established (reviewed in $[42,43]$ ).

Variations in oestrogen catabolism may also influence risk for breast cancer by causing differences in the cumulative exposure to oestrogen, by influencing the balance between different forms of oestrogen and by altering exposure to the various metabolites, some of which might have carcinogenic properties. In humans, oestrogens are catabolised into hydroxy-oestrogens such as $16 \alpha$-hydroxylated oestrogens and 2-hydroxylated (catechol) oestrogens, which are then converted into methoxylated metabolites. Polymorphisms in genes such as COMT, which is involved in the methylation of oestrogens to harmless metabolites, have been the subject of epidemiological studies [44]. Several studies have found women with the low-activity COMT allele to be at higher risk for breast cancer [45-47]. However, other studies have failed to find a significant association $[48,49]$ or have found COMT to be important only in certain histotypes or in conjunction with other exposures $[49,50]$.

\section{Exogenous oestrogens and breast cancer}

In the past 50 years, exposure to exogenous oestrogens from a variety of sources has become increasingly common, particularly from hormonal preparations for use as contraceptives or to combat the symptoms of the menopause. Hormonal contraception, using oestrogens and progestins in various forms and doses, is now one of the most widely used forms of contraception, being taken by 200 million women worldwide in 1996 [51]. Similarly, the prescription of hormone replacement therapy (HRT) for older women, containing oestrogens with or without progestins, has become common. In Britain, for example, $33 \%$ of women aged 50-64 are current users [52]. Given the high prevalence of exposure to these exogenous oestrogens, even small associated increases in risk for breast cancer could have a substantial effect on the incidence of breast cancer.

\section{Oral contraceptives and breast cancer}

In 1996, data from 54 published studies on use of the combined contraceptive pill (containing an oestrogen and a progestogen) in relationship to breast cancer risk were brought together in a pooled analysis [53]. Women who were currently using combined oral contraceptives or who had used them in the past 10 years were found to be at slightly higher risk of having breast cancer diagnosed (relative risk [95\% confidence interval] in current user, 1.24 [1.15-1.33]; 1-4 years after stopping, 1.16 [1.08-1.23]; 5-9 years after stopping, 1.07 [1.02-1.13]), although the associated cancers tended to be localised to the breast [53]. However, there was no evidence of a significant excess risk of having breast cancer diagnosed 10 or more (relative risk 1.01 [0.96-1.05]) [53]. More recent results are broadly compatible with these findings, but inconsistencies remain and formulations are changing; further research is therefore crucial [54-59].

\section{HRT and breast cancer}

So far there have been more than 60 analytical studies investigating the relationship between menopausal HRT and breast cancer risk. Data from these studies were brought together in a pooled analysis [7], which found that current users of HRT, or those who ceased use 1-4 years previously, had a $2.3 \%$ excess risk of being diagnosed with breast cancer for each year of use, an increase in risk that is comparable with the effect of delaying menopause for a year [7]. The excess risk of breast cancer among women who had used HRT for 5 years or longer was $35 \%$. This effect was reduced after ceasing use of HRT and had largely, if not wholly, disappeared after about 5 years. These results did not vary significantly by type of HRT, although the collaborative study had relatively little power to assess relationships with combined oestrogen-progestin therapy. More recent studies have reported that the long-term use of preparations containing progestins is more detrimental than the use of oestrogen alone $[60,61]$. Recent data from three randomised controlled trials have confirmed that exposure to oestrogens plus progestins for 5 years is associated with an approximate $26-30 \%$ increase in risk for breast cancer [62].

\section{Phyto-oestrogens and breast cancer}

The observation that breast cancer rates are lower in most Asian countries than in Western Europe and the USA [63] has given risen to hypotheses about the possible protective effects of foods rich in phyto-oestrogens, particularly soybeans, which form an important part of the diet in several Asian countries [64]. Phyto-oestrogens are naturally occurring plant compounds (or their metabolites) that are effectively weak exogenous oestrogens because they can mimic or modulate the actions of more potent endogenous oestrogens, usually by binding to oestrogen receptors (ERs) [65]. It has also been suggested that they might reduce risk by altering oestrogen metabolism away from the production of genotoxic metabolites [66] or through non-oestrogenic pathways [65].

Results from numerous animal studies suggest that high intake of soy may confer a protective effect against breast cancer [67], but the findings from studies in humans remain equivocal [68]. Two early case-control analyses suggested that high levels of dietary isoflavone intake may be protective against breast cancer in premenopausal women $[69,70]$, but results from later analytical studies of adult exposure and breast cancer risk have been inconsistent [68]. Two recent case-control studies have suggested that a high intake of isoflavone-rich foods during adolescence may have a protective effect on risk for 
breast cancer in adulthood [71,72]. These findings support the possibility that exposure to phyto-oestrogens at critical periods of development might be an important determinant of risk for breast cancer.

\section{The proliferative effects of oestrogen}

Oestrogens have a marked proliferative effect on breast epithelial tissue in model systems [73]. Both endogenous and exogenous oestrogens stimulate breast epithelial cell mitosis, increasing the number of cell divisions and thus the opportunity for random genetic errors $[1,74]$. Oestrogen concentrations may be important at all stages in the development of breast neoplasms because the hormonal stimulus to cell division continues all along the progression pathway [75]. The proliferative effects of oestrogens are brought about on entering target cells, where they bind with a receptor protein, which then binds to hormone response elements on the nuclear DNA, activating or suppressing specific sequences in the regulatory regions of genes responsive to oestrogen that control cell growth and differentiation [76].

The possible role of oestrogens as mutagens in the initiation of breast tumorigenesis has also received much scrutiny. Although early experimental data suggested that oestradiol did not have any mutagenic properties because no mutagenic activity was found in either bacterial or mammalian cell test systems, more recent research has suggested that oestrogens, and to a greater extent their metabolites including catechol oestrogens and reactive semiquinone/quinone intermediates, may act as weak procarcinogens. They might induce direct and indirect freeradical-mediated DNA damage, genetic instability, and mutations in cells in culture and in vivo [77]. However, even if oestrogens can induce genetic damage, the data overall suggest that proliferative effects are likely to be the most important mechanism by which this hormone acts to influence the development of breast cancer.

It has also been suggested that oestrogens might have an important influence on risk for developing breast cancer through effects before the initiation of the disease [78]. Raised oestrogen levels during fetal life have been shown to influence morphology of the mammary gland [79], and increased levels are also thought to be responsible for the persistence of epithelial structures (terminal end buds) that are known to be sites of malignant transformation [80]. Furthermore, results from animal models and indirect human evidence indicate that exposure to elevated oestrogen levels in utero may increase the risk for developing breast cancer in adulthood [79,81].

Epidemiological studies investigating the relationship between breast cancer risk and oestrogen exposure in utero have examined several perinatal factors, such as high birth weight $[82,83]$. In six out of seven epidemiologi- cal studies, birth weight has been found to be positively associated with risk for breast cancer [82,84], although several studies have also found low birth weight (less than $2500 \mathrm{~g}$ ) to be associated with a higher risk for breast cancer [84]. This intriguing field relates to the suggestion that certain perinatal factors are associated with high concentrations of maternal oestrogens in pregnancy [78] or high levels of oestrogens in the infant postnatally [85]. However, these associations remain to be confirmed [86].

\section{Sensitivity to oestrogen}

The sensitivity of breast tissue to oestrogen is dependent on the levels and types of ERs [76] and it is possible that variation in breast cancer risk is, in part, attributable to inter-individual variation in receptor levels in normal breast tissue [87]. ER levels have been found to vary by age, menopausal status and perhaps by ethnic group $[88,89]$. Sensitivity of breast tissue to oestrogens might also be determined by the balance between the two ER types, ER- $\alpha$ and ER- $\beta$. ER- $\beta$ has a lower affinity for oestrogen than ER- $\alpha$ and may decrease the sensitivity of ER- $\alpha$ to oestrogen [90].

\section{Other hormones and breast cancer risk}

Whereas early hypotheses focused on oestrogens as important hormonal determinants of breast cancer risk [91], current epidemiological and experimental data indicate that other hormones, such as progesterone [1], prolactin [5] and testosterone [6], are also important in the aetiology of breast cancer.

It has been proposed that progesterone augments the effects of oestrogens on breast cancer development [1], and this hypothesis has gained support from several lines of evidence. Breast cell proliferation has been found to be greatest during the luteal phase of the menstrual cycle [1], when levels of progesterone are at their highest, and a cross-sectional study of women undergoing breast biopsies found that the mitotic activity in the terminal ductal lobular unit of the breast was greater in women taking combined hormone preparations than in women using oestrogen alone [92]. Furthermore, recent data indicate that hormone replacement therapies containing both oestrogens and progestogens have a greater detrimental effect on risk for breast cancer than preparations containing oestrogens alone [61]. Progestins, like oestrogens, are thought to exert their effects mainly through binding to nuclear receptor proteins.

Epidemiological studies of prolactin have found that circulating levels of the hormone are correlated with some established risk factors for breast cancer; for example, concentrations are higher in nulliparous than parous women [93] and higher among women using certain types of oral contraceptives than among those who were not $[94,95]$. High concentrations of prolactin have also been 
found to be associated with increased risk for breast cancer in prospective studies in postmenopausal women [5]. In the largest prospective study so far, more than a doubling in risk for breast cancer was observed among women in the highest $25 \%$ of the prolactin distribution relative to those in the lowest $25 \%$, independent of the effects of concentrations of circulating oestrogens, androgens and insulin-like growth factor-1 [96]. Prolactin, produced at the endocrine and autocrine/paracrine levels, acts to stimulate the proliferation, survival and motility of mammary epithelial cells through its interaction with receptors at the cell surface [5].

Testosterone might also have a role in the aetiology of breast cancer [6]. Results from a recent pooled analysis of prospective studies in postmenopausal women estimated that breast cancer risk among women in the top quintile of exposure to endogenous testosterone was more than double that of women in the lowest quintile [2]. However, the mechanisms by which testosterone might influence the risk for developing breast cancer remain unclear, as do the effects of the androgen on the risk for premenopausal breast cancer [6]. It may be that, in postmenopausal women at least, testosterone is converted to oestrogen in the breast.

\section{Preventive strategies}

The epidemiological evidence suggests that the risk of breast cancer might be reduced by lowering lifetime exposure to oestrogens through changes in lifestyle and reproductive behaviour. At present the only clear oestrogen-related risk factor for breast cancer that is amenable to change is obesity after the menopause. Thus, prudent advice is to maintain weight such that body mass is below $25 \mathrm{~kg} / \mathrm{m}^{2}$. Other lifestyle changes that may have protective effects mediated by oestrogens include minimising alcohol consumption and taking regular physical exercise. Recent data suggest, too, that long-term use of HRT should be avoided, unless there are strong clinical indications. Voluntary changes in most of the important reproductive risk factors such as parity and ages at menarche and menopause are not realistic, but extended breast feeding will produce a small decrease in breast cancer risk, in addition to its benefits for the child.

More radical measures including surgery, such as bilateral prophylactic oophorectomy and/or mastectomy, or chemoprophylaxis may be considered for particularly susceptible subgroups, such as those with a family history of breast cancer or characteristics predisposing them to exposure to high oestrogen levels. Bilateral oophorectomy has been found to result in a $50-70 \%$ reduction in breast cancer risk [97] although, in general, studies have focused only on women with mutations in BRCA1/BRCA2. Trial data show that the partial ER agonist tamoxifen and other ER modulators such as raloxifene [98] reduce the incidence of primary ER-positive breast cancer [3,99]. Aromatase inhibitors [100], which suppress the peripheral conversion of androstenedione to oestradiol through inhibition of the aromatase enzyme, and agonists of gonadotrophin-releasing hormone, which suppress ovarian function in premenopausal women, have been shown to be effective in the treatment of early breast cancer [101] and may be developed for chemoprevention [1].

As these chemopreventatives may themselves be associated with detrimental effects, clinicians try to identify women at particularly high risk for breast cancer, for whom benefits of such interventions are likely to outweigh the risks $[102,103]$. One method of identifying women at high risk for the disease is to use mathematical models; one such tool is the Gail model, which uses data on risk factors to predict individualised risk for breast cancer [104].

\section{Conclusion}

Oestrogens have a key role in the aetiology of breast cancer, probably because of their proliferative effects. Current data suggest that these steroid hormones mediate the relationship between breast cancer and many established risk factors, such as age at menarche, age at menopause, and obesity in postmenopausal women. However, the effects of other risk factors, such as parity and breast feeding, may not be explained only by oestrogens; other hormones such as progesterone, prolactin and testosterone may also be important. More work is needed to clarify the effects of hormones on risk for breast cancer and the mechanisms involved, as well as to unravel the complex environmental and genetic determinants of endogenous hormone concentrations.

\section{Competing interests}

None declared.

\section{References}

1. Pike MC, Spicer DV, Dahmoush L, Press MF: Estrogens, progestogens, normal breast cell proliferation, and breast cancer risk. Epidemiol Rev 1993, 15:17-35.

2. Endogenous Hormones and Breast Cancer Collaborative Group: Endogenous sex hormones and breast cancer in postmenopausal women: reanalysis of nine prospective studies. $J$ Natl Cancer Inst 2002, 94:606-616.

3. Cuzick J, Powles T, Veronesi U, Forbes J, Edwards R, Ashley S, Boyle P: Overview of the main outcomes in breast-cancer prevention trials. Lancet 2003, 361:296-300.

4. Dao TL: The role of ovarian steroid hormones in mammary carcinogenesis. In: Hormones and Breast Cancer. Edited by Pike MC, Siiteri PK, Welsch CW. Cold Spring Harbor, New York: Cold Spring Harbor Laboratory; 1981:281-295.

5. Clevenger CV, Furth PA, Hankinson SE, Schuler LA: The role of prolactin in mammary carcinoma. Endocr Rev 2003, 24:1-27.

6. Lillie EO, Bernstein L, Ursin G: The role of androgens and polymorphisms in the androgen receptor in the epidemiology of breast cancer. Breast Cancer Res 2003, 5:164-173.

7. Collaborative Group on Hormonal Factors in Breast Cancer: Breast cancer and hormone replacement therapy: collaborative reanalysis of data from 51 epidemiological studies of 52,705 women with breast cancer and 108,411 women without breast cancer. Lancet 1997, 350:1047-1059. 
8. Eerola $\mathrm{H}$, Aittomaki $\mathrm{K}$, Asko-Seljavaara $\mathrm{S}$, Nevanlinna $\mathrm{H}$, von Smitten K: Hereditary breast cancer and handling of patients at risk. Scand J Surg 2002, 91:280-287.

9. Hunter DJ, Spiegelman D, Adami HO, van den Brandt PA, Folsom AR, Goldbohm RA, Graham S, Howe GR, Kushi LH, Marshall JR, Miller AB, Speizer FE, Willett W, Wolk A, Yaun SS: Non-dietary factors as risk factors for breast cancer, and as effect modifiers of the association of fat intake and risk of breast cancer. Cancer Causes Control 1997, 8:49-56.

10. Key TJ, Verkasalo PK, Banks E: Epidemiology of breast cancer. Lancet Oncol 2001, 2:133-140.

11. Liu Q, Wuu J, Lambe M, Hsieh SF, Ekbom A, Hsieh CC: Transient increase in breast cancer risk after giving birth: postpartum period with the highest risk (Sweden). Cancer Causes Control 2002, 13:299-305.

12. Collaborative Group on Hormonal Factors in Breast Cancer: Breast cancer and breastfeeding: collaborative reanalysis of individual data from 47 epidemiological studies in 30 countries, including 50302 women with breast cancer and 96973 women without the disease. Lancet 2002, 360:187-195.

13. Ewertz M, Duffy SW, Adami HO, Kvale G, Lund E, Meirik O, Mellemgaard A, Soini I, Tulinius $\mathrm{H}$ : Age at first birth, parity and risk of breast cancer: a meta-analysis of 8 studies from the Nordic countries. Int J Cancer 1990, 46:597-603.

14. Russo J, Wilgus G, Russo $\mathrm{IH}$ : Susceptibility of the mammary gland to carcinogenesis: I. Differentiation of the mammary gland as determinant of tumor incidence and type of lesion. Am J Pathol 1979, 96:721-736.

15. Collaborative Group on Hormonal Factors in Breast Cancer: Alcohol, tobacco and breast cancer: collaborative reanalysis of individual data from $\mathbf{5 3}$ epidemiological studies, including $\mathbf{5 8 , 5 1 5}$ women with breast cancer and 95,067 women without the disease. Br J Cancer 2002, 87:1234-1245.

16. International Agency for Research on Cancer: Weight Control and Physical Activity. Lyon, France: IARC Press; 2002.

17. Dorgan JF, Baer DJ, Albert PS, Judd JT, Brown ED, Corle DK, Campbell WS, Hartman TJ, Tejpar AA, Clevidence BA, Giffen CA, Chandler DW, Stanczyk FZ, Taylor PR: Serum hormones and the alcohol-breast cancer association in postmenopausal women. J Natl Cancer Inst 2001, 93:710-715.

18. Hankinson S, Hunter D: Breast cancer. In: Textbook of Cancer Epidemiology. Edited by Adami HO, Hunter D, Trichopoulos D. Oxford: Oxford University Press; 2002:301-339.

19. Huang Z, Hankinson SE, Colditz GA, Stampfer MJ, Hunter DJ, Manson JE, Hennekens $\mathrm{CH}$, Rosner B, Speizer FE, Willett WC: Dual effects of weight and weight gain on breast cancer risk. JAMA 1997, 278:1407-1411.

20. Hoffman-Goetz L, Apter D, Demark-Wahnefried W, Goran Ml, McTiernan A, Reichman ME: Possible mechanisms mediating an association between physical activity and breast cancer. Cancer 1998, 83 (Suppl 3):621-628.

21. Thune I, Brenn T, Lund E, Gaard M: Physical activity and the risk of breast cancer. N Engl J Med 1997, 336:1269-1275.

22. Feicht CB, Johnson TS, Martin BJ, Sparkes KE, Wagner WW Jr: Secondary amenorrhoea in athletes. Lancet 1978, 2:11451146.

23. Shangold MM, Levine HS: The effect of marathon training upon menstrual function. Am J Obstet Gynecol 1982, 143:862-869.

24. Moisan J, Meyer F, Gingras S: Leisure physical activity and age at menarche. Med Sci Sports Exerc 1991, 23:1170-1175.

25. Bernstein L, Ross RK, Lobo RA, Hanisch R, Krailo MD, Henderson BE: The effects of moderate physical activity on menstrual cycle patterns in adolescence: implications for breast cancer prevention. Br J Cancer 1987, 55:681-685.

26. Harlow SD, Matanoski GM: The association between weight, physical activity, and stress and variation in the length of the menstrual cycle. Am J Epidemiol 1991, 133:38-49.

27. Cooper GS, Sandler DP, Whelan EA, Smith KR: Association of physical and behavioral characteristics with menstrual cycle patterns in women age 29-31 years. Epidemiology 1996, 7: 624-628.

28. Key TJ: Serum oestradiol and breast cancer risk. Endocr Relat Cancer 1999, 6:175-180.

29. Stanczyk FZ: Steroid hormones. In: Mishell's Textbook of Infertility, Contraception, and Reproductive Endocrinology. 4th edition. Edited by Lobo RA, Mishell DR, Paulson RJ, Shoupe D. Oxford: Blackwell Science; 1997:47-66.
30. Onland-Moret NC, Kaaks R, van Noord PAH, Rinaldi S, Key T, Grobbee DE, Peeters PHM: Urinary endogenous sex hormone levels and the risk of postmenopausal breast cancer. $\mathrm{Br} J$ Cancer 2003, 88:1394-1399.

31. Wysowski DK, Comstock GW, Helsing KJ, Lau HL: Sex hormone levels in serum in relation to the development of breast cancer. Am J Epidemiol 1987, 125:791-799.

32. Helzlsouer KJ, Alberg AJ, Bush TL, Longcope C, Gordon GB, Comstock GW: A prospective study of endogenous hormones and breast cancer. Cancer Detect Prev 1994, 18:79-85.

33. Rosenberg CR, Pasternack BS, Shore RE, Koenig KL, Toniolo PG: Premenopausal estradiol levels and the risk of breast cancer: a new method of controlling for day of the menstrual cycle. Am J Epidemiol 1994, 140:518-525.

34. Thomas HV, Key TJ, Allen DS, Moore JW, Dowsett M, Fentiman IS, Wang DY: A prospective study of endogenous serum hormone concentrations and breast cancer risk in premenopausal women on the island of Guernsey. $\mathrm{Br} J$ Cancer 1997, 75:1075-1079.

35. Kabuto M, Akiba S, Stevens RG, Neriishi K, Land CE: A prospective study of estradiol and breast cancer in Japanese women. Cancer Epidemiol Biomarkers Prev 2000, 9:575-579.

36. Thomas HV, Key TJ, Allen DS, Moore JW, Dowsett M, Fentiman IS, Wang DY: A prospective study of endogenous serum hormone concentrations and breast cancer risk in postmenopausal women on the island of Guernsey. $\mathrm{Br} J$ Cancer 1997, 76:401-405.

37. Michaud DS, Manson JE, Spiegelman D, Barbieri RL, Sepkovic DW, Bradlow HL, Hankinson SE: Reproducibility of plasma and urinary sex hormone levels in premenopausal women over a one-year period. Cancer Epidemiol Biomarkers Prev 1999, 8: 1059-1064.

38. Yu H, Shu XO, Shi R, Dai Q, Jin F, Gao YT, Li BD, Zheng W: Plasma sex steroid hormones and breast cancer risk in Chinese women. Int J Cancer 2003, 105:92-97.

39. Feigelson HS, Ross RK, Yu MC, Coetzee GA, Reichardt JK, Henderson BE: Genetic susceptibility to cancer from exogenous and endogenous exposures. J Cell Biochem Suppl 1996, 25: 15-22.

40. Feigelson HS, McKean-Cowdin R, Coetzee GA, Stram DO, Kolonel LN, Henderson BE: Building a multigenic model of breast cancer susceptibility: CYP17 and HSD17B1 are two important candidates. Cancer Res 2001, 61:785-789.

41. Kristensen VN, Borresen-Dale AL: Molecular epidemiology of breast cancer: genetic variation in steroid hormone metabolism. Mutat Res 2000, 462:323-333.

42. Dunning AM, Healey CS, Pharoah PD, Teare MD, Ponder BA, Easton DF: A systematic review of genetic polymorphisms and breast cancer risk. Cancer Epidemiol Biomarkers Prev 1999, 8: 843-854.

43. Thompson PA, Ambrosone C: Molecular epidemiology of genetic polymorphisms in estrogen metabolizing enzymes in human breast cancer. J Natl Cancer Inst Monogr 2000:125134.

44. Comings DE, Gade-Andavolu R, Cone LA, Muhleman D, MacMurray JP: A multigene test for the risk of sporadic breast carcinoma. Cancer 2003, 97:2160-2170.

45. Yim DS, Parkb SK, Yoo KY, Yoon KS, Chung HH, Kang HL, Ahn SH, Noh DY, Choe KJ, Jang IJ, Shin SG, Strickland PT, Hirvonen A, Kang D: Relationship between the Val158Met polymorphism of catechol O-methyl transferase and breast cancer. Pharmacogenetics 2001, 11:279-286.

46. Huang CS, Chern HD, Chang KJ, Cheng CW, Hsu SM, Shen CY: Breast cancer risk associated with genotype polymorphism of the estrogen-metabolizing genes CYP17, CYP1A1, and COMT: a multigenic study on cancer susceptibility. Cancer Res 1999, 59:4870-4875.

47. Lavigne JA, Helzlsouer KJ, Huang HY, Strickland PT, Bell DA, Selmin O, Watson MA, Hoffman S, Comstock GW, Yager JD: An association between the allele coding for a low activity variant of catechol-O-methyltransferase and the risk for breast cancer. Cancer Res 1997, 57:5493-5497.

48. Kocabas NA, Sardas S, Cholerton S, Daly AK, Karakaya AE: Cytochrome P450 CYP1B1 and catechol O-methyltransferase (COMT) genetic polymorphisms and breast cancer susceptibility in a Turkish population. Arch Toxicol 2002, 76:643-649. 
49. Wedren S, Rudqvist TR, Granath F, Weiderpass E, IngelmanSundberg M, Persson I, Magnusson C: Catechol-O-methyltransferase gene polymorphism and post-menopausal breast cancer risk. Carcinogenesis 2003, 24:681-687.

50. Mitrunen K, Kataja V, Eskelinen M, Kosma VM, Kang D, Benhamou $\mathrm{S}$, Vainio H, Uusitupa M, Hirvonen A: Combined COMT and GST genotypes and hormone replacement therapy associated breast cancer risk. Pharmacogenetics 2002, 12:67-72.

51. Beral V, Hermon C, Reeves G, Key T: Breast cancer trends in women in Sweden, the UK, and the USA in relation to their past use of oral contraceptives. In: Hormonal Carcinogenesis II. Proceedings of the Second International Symposium. Edited by Li JJ, Li SA, Gustafsson J-A, Nandi S, Sekely LI. New York: Springer-Verlag; 1996:99-106.

52. Million Women Study Collaborators: Patterns of use of hormone replacement therapy in one million women in Britain, 1996-2000. BJOG 2002, 109:1319-1330.

53. Collaborative Group on Hormonal Factors in Breast Cancer: Breast cancer and hormonal contraceptives: collaborative reanalysis of individual data on 53297 women with breast cancer and 100239 women without breast cancer from 54 epidemiological studies. Lancet 1996, 347:1713-1727.

54. Hankinson SE, Colditz GA, Manson JE, Willett WC, Hunter DJ, Stampfer MJ, Speizer FE: A prospective study of oral contraceptive use and risk of breast cancer (Nurses' Health Study, United States). Cancer Causes Control 1997, 8:65-72.

55. Magnusson CM, Persson IR, Baron JA, Ekbom A, Bergstrom R, Adami HO: The role of reproductive factors and use of oral contraceptives in the aetiology of breast cancer in women aged 50 to 74 years. Int J Cancer 1999, 80:231-236.

56. Kumle M, Weiderpass E, Braaten T, Persson I, Adami HO, Lund E: Use of oral contraceptives and breast cancer risk: The Norwegian-Swedish Women's Lifestyle and Health Cohort Study. Cancer Epidemiol Biomarkers Prev 2002, 11:1375-1381.

57. Marchbanks PA, McDonald JA, Wilson HG, Folger SG, Mandel MG, Daling JR, Bernstein L, Malone KE, Ursin G, Strom BL, Norman SA, Wingo PA, Burkman RT, Berlin JA, Simon MS, Spirtas R, Weiss LK: Oral contraceptives and the risk of breast cancer. N Engl J Med 2002, 346:2025-2032.

58. Althuis MD, Brogan DR, Coates RJ, Daling JR, Gammon MD, Malone KE, Schoenberg JB, Brinton LA: Hormonal content and potency of oral contraceptives and breast cancer risk among young women. Br J Cancer 2003, 88:50-57.

59. Dumeaux V, Alsaker E, Lund E: Breast cancer and specific types of oral contraceptives: a large Norwegian cohort study. Int J Cancer 2003, 105:844-850.

60. Ross RK, Paganini-Hill A, Wan PC, Pike MC: Effect of hormone replacement therapy on breast cancer risk: estrogen versus estrogen plus progestin. J Natl Cancer Inst 2000, 92:328-332.

61. Olsson HL, Ingvar C, Bladstrom A: Hormone replacement therapy containing progestins and given continuously increases breast carcinoma risk in Sweden. Cancer 2003, 97: 1387-1392.

62. Beral V, Banks E, Reeves G: Evidence from randomised trials on the long-term effects of hormone replacement therapy. Lancet 2002, 360:942-944.

63. International Agency for Research on Cancer: Globocan. 5th edition. Lyon: IARC, 2001

64. Setchell KD, Borriello SP, Hulme P, Kirk DN, Axelson M: Nonsteroidal estrogens of dietary origin: possible roles in hormone-dependent disease. Am J Clin Nutr 1984, 40:569578.

65. UK Food Standards Agency Committee on Toxicity: Working Group on Phytoestrogens Draft Report, 2002. http://www. foodstandards.gov.uk/multimedia/webpage/phytoreportworddocs

66. Xu X, Duncan AM, Wangen KE, Kurzer MS: Soy consumption alters endogenous estrogen metabolism in postmenopausal women. Cancer Epidemiol Biomarkers Prev 2000, 9:781-786.

67. Bingham SA, Atkinson C, Liggins J, Bluck L, Coward A: Phytooestrogens: where are we now? Br J Nutr 1998, 79:393-406.

68. Peeters PHM, Keinan-Boker L, van der Schouw YT, Grobbee DE: Phytoestrogens and breast cancer risk. Breast Cancer Res Treat 2003, 77:171-183.

69. Lee HP, Gourley L, Duffy SW, Esteve J, Lee J, Day NE: Risk factors for breast cancer by age and menopausal status: a case-control study in Singapore. Cancer Causes Control 1992, 3:313-322.
70. Hirose K, Tajima K, Hamajima N, Inoue M, Takezaki T, Kuroishi T, Yoshida M, Tokudome S: A large-scale, hospital-based casecontrol study of risk factors of breast cancer according to menopausal status. Jpn J Cancer Res 1995, 86:146-154.

71. Shu XO, Jin F, Dai Q, Wen W, Potter JD, Kushi LH, Ruan Z, Gao YT, Zheng W: Soyfood intake during adolescence and subsequent risk of breast cancer among Chinese women. Cancer Epidemiol Biomarkers Prev 2001, 10:483-488.

72. Wu AH, Wan P, Hankin J, Tseng CC, Yu MC, Pike MC: Adolescent and adult soy intake and risk of breast cancer in AsianAmericans. Carcinogenesis 2002, 23:1491-1496.

73. McManus MJ, Welsch CW: The effect of estrogen, progesterone, thyroxine, and human placental lactogen on DNA synthesis of human breast ductal epithelium maintained in athymic nude mice. Cancer 1984, 54:1920-1927.

74. Cohen SM, Ellwein LB: Cell proliferation in carcinogenesis. Science 1990, 249:1007-1011.

75. Henderson BE, Feigelson HS: Hormonal carcinogenesis. Carcinogenesis 2000, 21:427-433.

76. Clemons M, Goss P: Estrogen and the risk of breast cancer. $N$ Engl J Med 2001, 344:276-285.

77. Jefcoate CR, Liehr JG, Santen RJ, Sutter TR, Yager JD, Yue W, Santner SJ, Tekmal R, Demers L, Pauley R, Naftolin F, Mor G, Berstein L: Tissue-specific synthesis and oxidative metabolism of estrogens. J Natl Cancer Inst Monogr 2000:95-112.

78. Trichopoulos D: Hypothesis: does breast cancer originate in utero? Lancet 1990, 335:939-940.

79. Hilakivi-Clarke L, Cho E, Raygada M, Kenney N: Alterations in mammary gland development following neonatal exposure to estradiol, transforming growth factor alpha, and estrogen receptor antagonist ICI 182,780. J Cell Physiol 1997, 170:279289.

80. Russo $\mathrm{IH}$, Russo J: Role of hormones in mammary cancer initiation and progression. J Mammary Gland Biol Neoplasia 1998, 3:49-61.

81. McCormack VA, dos Santos Silva I, De Stavola BL, Mohsen R, Leon DA, Lithell HO: Fetal growth and subsequent risk of breast cancer: results from long term follow up of Swedish cohort. BMJ 2003, 326:248-251.

82. Potischman N, Troisi R: In-utero and early life exposures in relation to risk of breast cancer. Cancer Causes Control 1999, 10:561-573.

83. Kaijser M, Granath F, Jacobsen G, Cnattingius S, Ekbom A: Maternal pregnancy estriol levels in relation to anamnestic and fetal anthropometric data. Epidemiology 2000, 11:315-319.

84. Mellemkjaer L, Olsen ML, Sorensen HT, Thulstrup AM, Olsen J, Olsen JH: Birth weight and risk of early-onset breast cancer (Denmark). Cancer Causes Contro/ 2003, 14:61-64.

85. Sedin G, Bergquist C, Lindgren PG: Ovarian hyperstimulation syndrome in preterm infants. Pediatr Res 1985, 19:548-552.

86. Peck JD, Hulka BS, Savitz DA, Baird D, Poole C, Richardson BE: Accuracy of fetal growth indicators as surrogate measures of steroid hormone levels during pregnancy. Am J Epidemiol 2003, 157:258-266.

87. Khan SA, Rogers MA, Obando JA, Tamsen A: Estrogen receptor expression of benign breast epithelium and its association with breast cancer. Cancer Res 1994, 54:993-997.

88. Lawson JS, Field AS, Champion S, Tran D, Ishikura H, Trichopoulos D: Low oestrogen receptor alpha expression in normal breast tissue underlies low breast cancer incidence in Japan. Lancet 1999, 354:1787-1788.

89. Shoker BS, Jarvis C, Sibson DR, Walker C, Sloane JP: Oestrogen receptor expression in the normal and pre-cancerous breast. J Pathol 1999, 188:237-244.

90. Hall JM, McDonnell DP: The estrogen receptor beta-isoform (ERbeta) of the human estrogen receptor modulates ERalpha transcriptional activity and is a key regulator of the cellular response to estrogens and antiestrogens. Endocrinology 1999, 140:5566-5578.

91. Korenman SG: Oestrogen window hypothesis of the aetiology of breast cancer. Lancet 1980, 1:700-701.

92. Hofseth LJ, Raafat AM, Osuch JR, Pathak DR, Slomski CA Haslam SZ: Hormone replacement therapy with estrogen or estrogen plus medroxyprogesterone acetate is associated with increased epithelial proliferation in the normal postmenopausal breast. J Clin Endocrinol Metab 1999, 84:45594565 . 
93. Kwa HG, Cleton F, Bulbrook RD, Wang DY, Hayward JL: Plasma prolactin levels and breast cancer: relation to parity, weight and height, and age at first birth. Int J Cancer 1981, 28:31-34.

94. Ismail MS, Serour GI, Torsten U, Weitzel H, Berlien HP: Elevated serum prolactin level with high-dose estrogen contraceptive pills. Eur J Contracept Reprod Health Care 1998, 3:45-50.

95. Wiegratz I, Kutschera E, Lee JH, Moore C, Mellinger U, Winkler $\mathrm{UH}$, Kuhl $\mathrm{H}$ : Effect of four different oral contraceptives on various sex hormones and serum-binding globulins. Contraception 2003, 67:25-32.

96. Hankinson SE, Willett WC, Michaud DS, Manson JE, Colditz GA Longcope C, Rosner B, Speizer FE: Plasma prolactin levels and subsequent risk of breast cancer in postmenopausal women. J Natl Cancer Inst 1999, 91:629-634.

97. Rebbeck TR, Lynch HT, Neuhausen SL, Narod SA, Van't Veer L, Garber JE, Evans G, Isaacs C, Daly MB, Matloff E, Olopade OI, Weber BL: Prophylactic oophorectomy in carriers of BRCA1 or BRCA2 mutations. N Engl J Med 2002, 346:1616-1622.

98. Cummings SR, Eckert S, Krueger KA, Grady D, Powles TJ, Cauley JA, Norton L, Nickelsen T, Bjarnason NH, Morrow M, Lippman ME, Black D, Glusman JE, Costa A, Jordan VC: The effect of raloxifene on risk of breast cancer in postmenopausal women: results from the MORE randomized trial. Multiple Outcomes of Raloxifene Evaluation. JAMA 1999, 281:2189-2197.

99. Gelber RD, Cole BF, Goldhirsch A Rose C, Fisher B, Osborne CK, Boccardo F, Gray R, Gordon NH, Bengtsson NO, Sevelda P: Adjuvant chemotherapy plus tamoxifen compared with tamoxifen alone for postmenopausal breast cancer: metaanalysis of quality-adjusted survival. Lancet 1996, 347:10661071.

100. Goss PE, Strasser K: Aromatase inhibitors in the treatment and prevention of breast cancer. J Clin Oncol 2001, 19:881894.

101. Jonat W, Kaufmann M, Sauerbrei W, Blamey R, Cuzick J, Namer M, Fogelman I, de Haes JC, de Matteis A, Stewart A, Eiermann W, Szakolczai I, Palmer M, Schumacher M, Geberth M, Lisboa B: Goserelin versus cyclophosphamide, methotrexate, and fluorouracil as adjuvant therapy in premenopausal patients with node-positive breast cancer: The Zoladex Early Breast Cancer Research Association Study. J Clin Oncol 2002, 20:46284635.

102. Clamp A, Danson S, Clemons M: Hormonal risk factors for breast cancer: identification, chemoprevention, and other intervention strategies. Lancet Oncol 2002, 3:611-619.

103. Domchek SM, Eisen A, Calzone K, Stopfer J, Blackwood A, Weber BL: Application of breast cancer risk prediction models in clinical practice. J Clin Oncol 2003, 21:593-601.

104. Gail MH, Brinton LA, Byar DP, Corle DK, Green SB, Schairer C, Mulvihill JJ: Projecting individualized probabilities of developing breast cancer for white females who are being examined annually. J Natl Cancer Inst 1989, 81:1879-1886.

\section{Correspondence}

Ruth Travis, Cancer Research UK, Epidemiology Unit, University of Oxford, Oxford OX2 6HE, UK. Tel: 01865 302234; fax: 01865 310545; e-mail: ruth.travis@cancer.org.uk 